\title{
Article \\ Effect of Various Mulch Materials on Chemical Properties of Soil, Leaves and Shoot Characteristics in Dendrocalamus Latiflorus Munro Forests
}

\author{
Lili Fan ${ }^{1}{ }^{\circledR}$, Ting Zhao ${ }^{1}$, Muhammad Waqqas Khan Tarin ${ }^{2}{ }^{\circledR}$, Yongzhen Han ${ }^{1}$, Wenfeng Hu ${ }^{1}$, Jundong Rong ${ }^{1}$, \\ Tianyou $\mathrm{He}^{2}$ and Yushan Zheng ${ }^{1,2, * \mathbb{B}}$ \\ 1 College of Forestry, Fujian Agriculture and Forestry University, Fujian 350002, China; \\ 2180428002@fafu.edu.cn (L.F.); zhaotingdada@163.com (T.Z.); 3200422027@fafu.edu.cn (Y.H.); \\ 1200428007@fafu.edu.cn (W.H.); rongjd@fafu.edu.cn (J.R.) \\ 2 College of Landscape Architecture, Fujian Agriculture and Forestry University, Fujian 350002, China; \\ waqas_tarin@yahoo.com (M.W.K.T.); heitianyou@fafu.edu.cn (T.H.) \\ * Correspondence: zys1960@163.com
}

check for updates

Citation: Fan, L.; Zhao, T.; Tarin, M.W.K.; Han, Y.; Hu, W.; Rong, J.; He, T.; Zheng, Y. Effect of Various Mulch Materials on Chemical Properties of Soil, Leaves and Shoot Characteristics in Dendrocalamus Latiflorus Munro Forests. Plants 2021, 10, 2302. https://doi.org/10.3390/ plants10112302

Academic Editor: Oleg Chertov

Received: 15 September 2021

Accepted: 22 October 2021

Published: 26 October 2021

Publisher's Note: MDPI stays neutral with regard to jurisdictional claims in published maps and institutional affiliations.

Copyright: (c) 2021 by the authors. Licensee MDPI, Basel, Switzerland. This article is an open access article distributed under the terms and conditions of the Creative Commons Attribution (CC BY) license (https:// creativecommons.org/licenses/by/ $4.0 /)$.

\begin{abstract}
The effectiveness of mulch treatments on soil quality as well as on the yield and growth rates of bamboo are major considerations and require further attention. The present work was aimed at assessing the impacts of three different mulch materials on soil available nutrients, biochemical traits, and growth patterns of Dendrocalamus latiflorus Munro. We found that relative to the control $(\mathrm{CK})$, bamboo leaves $(\mathrm{MB})$ and organic fertilizers $(\mathrm{MF})$ treatments significantly $(P<0.05)$ increased the number of bamboo shoots (47.5 and $22.7 \%$ ) and yield (21.4 and $9.1 \%)$, respectively. We observed that under MB and MF treatments, the concentrations of soil available nutrients (nitrogen, phosphorus, and potassium) increased and played a key role in the differences in chlorophyll, leaf carbohydrate contents (soluble sugar and starch) and were essential to promote bamboo shoot development. Furthermore, we infer from principal component analysis (PCA), that both MB and MF appear to be a better choice than rice husks (MR) to improve nutrient availability, biochemical traits of the leaves, and increased bamboo shoot productivity. Consequently, we suggest using organic fertilizers and bamboo leaves as mulch materials are effective for soil conservation to attain high-quality bamboo production.
\end{abstract}

Keywords: Dendrocalamus latiflorus Munro forests; mulch treatments; shooting; soil available nutrients; biochemical attributes

\section{Introduction}

Since the 1930s, mulch technology has been used for ecosystem modification in farmlands, forests, and urban landscapes [1]. There are several advantages to this process; mulches are known to buffer soil temperature [2], prevent evapotranspiration [3], and suppress weed germination and growth [4]. Moreover, the process can also protect soils from erosion and compaction caused by wind and water [1]. Finally, mulch can increase plant productivity by maintaining soil moisture, improving soil biological activity, and physicochemical characteristics [5]. Various mulch treatments, such as plastic film, organic materials, have diverse effects on soil physicochemical properties and plant growth [6]. Organic materials are widely used for the production of mulch materials including straw, chaff, bamboo leaves, wheat straw, organic fertilizer, etc. [7].

Bamboo is one of the key species in the world's forest reserves, with a total area of 31.5 million hectares, accounting for about $0.8 \%$ of the world's total forest area [8]. The mulch technology to the bamboo forest has been an innovative forest management practice, where the ground is covered with organic or inorganic materials to raise the soil temperature to ensure the early emergence of bamboo shoots and increase the yield of 
bamboo shoots [9]. Nevertheless, mulching on bamboo forest land may help to improve soil characteristics, enhance forest land productivity, and decrease soil erosion [10].

Various mulch materials have distinct effects on early emergence and increased yield of bamboo shoots. For instance, a greater number of Bambusa beecheyana var. pubescens (P.F.Li) W.C. Lin shoots can be produced under organic fertilizer mulches than that of bran mulches [11]. The chicken manure mulches can also significantly increase the yield of bamboo shoots [12]. In addition, the study on the coverage of Phyllostachys praecox prevernalis suggests that mixed mulches with chicken manure can prolong the shooting stage and significantly increase shoot yields after mulching $[13,14]$. The B. oldhamii Munro mulch with hulling has shown that bamboo shoots can be produced earlier, and their growth period can also be extended [15]. To date, studies have shown that the mulch materials such as rice husks, chicken manure, and other materials used in the P. edulis (Carriere) J. Houzeau forests, can promote the early emergence of bamboo shoots and increase the number of shoots and the yield [16].

Mulch can effectively improve plant production by enhancing soil quality [17]. During the decay process of organic mulch, cellulose and hemicellulose are decomposed by microorganisms, releasing nutrient elements, such as nitrogen $(\mathrm{N})$, phosphorus $(\mathrm{P})$, and potassium (K) into the soil [18]. As the mulching reduces the leaching of rainwater to the soil, with the obvious warming effect, the microbial activity is stimulated to improve the soil nutrient utilization and accelerate conversion efficiency $[19,20]$. Mulching can promote the absorption of $\mathrm{N}$ and $\mathrm{P}$ by plants and improve the quality of plants [21]. Plants absorb $\mathrm{P}$ to balance the increase in $\mathrm{N}$ into the soil, allowing them to fulfill the need for high forest productivity [22]. The increase of $\mathrm{N}$ under the mulch treatments can help to promote the synthesis of chlorophyll and soluble protein [23], whereas the rise of soil available P is related to the accumulation of sugar content to achieve an increase in yield [24]. Therefore, the increase of soil nutrients is the main effect of mulching [17]. Owing to the various advantages of mulch materials, the current study was designed to evaluate the response of Dendrocalamus latiflorus Munro using three distinct types of organic mulch materials.

D. latiflorus Munro is one of the most widely grown semitropical clumping bamboo species of southern China. D. latiflorus Munro with a high economic value can produce nutrient-rich bamboo shoots, which has great benefits to humans with increasing demand. Its bamboo products are conventionally used as the raw materials for the production of chopsticks, handicrafts, utensils, plywood, fiberboard, decorative multilayer boards, and building materials [25]. We expected that various mulch materials would have varied impacts on the chemical properties of soil, leaf biochemical traits, and growth responses of D. latiflorus Munro. Therefore, the present work was aimed to assess the impacts of three different mulch materials with the following objectives: (i) to examine the effects of different mulch materials on bamboo shooting characteristics and yield; (ii) to distinguish the effects of different mulch materials on leaf biochemical traits, the carbohydrate contents in the bamboo shoots, and the chemical properties of the soil; and (iii) to screen out the optimal mulch materials to maximize the shooting period. The study will provide scientific insights into cultivation management for the growth of D. latiflorus Munro shoot.

\section{Results}

\subsection{Impacts of Mulch Treatments on the Number of Shoots and Bamboo Yield}

Results suggested that the mulch materials increased the number of shoots and extended the period of shooting (Table 1). 
Table 1. The effect of mulch treatments on shooting periods and the number of shoots.

\begin{tabular}{|c|c|c|c|c|}
\hline & Emergence/Days & Shooting Duration/Days & $\begin{array}{c}\text { Number of Shoots/ } \\
\text { (Individual Hectare }^{-2} \text { ) }\end{array}$ & $\begin{array}{c}\text { Bamboo Shoot Yield/ } \\
\left(\mathrm{Kg} \mathrm{Hectare}^{-2}\right)\end{array}$ \\
\hline CK & / & $131.0 \pm 0.9^{b}$ & $10,083.3 \pm 659.0^{c}$ & $22,773.3 \pm 305.5^{a}$ \\
\hline MB & $16.0 \pm 1.3^{\mathrm{a}}$ & $146.0 \pm 4.1^{\mathrm{a}}$ & $14,875.0 \pm 641.6^{\mathrm{a}}$ & $27,653.3 \pm 4061.1^{\mathrm{a}}$ \\
\hline MR & $19.0 \pm 1.9^{\mathrm{a}}$ & $149.0 \pm 2.0^{\mathrm{a}}$ & $10,500.7 \pm 469.6^{c}$ & $23,360.0 \pm 1829.8^{a}$ \\
\hline MF & $8.0 \pm 1.1^{\mathrm{a}}$ & $146.0 \pm 3.2^{\mathrm{a}}$ & $12,375.3 \pm 416.7^{\mathrm{b}}$ & $24,853.3 \pm 1649.3^{a}$ \\
\hline
\end{tabular}

Where MB: bamboo leaves mulch, MR: rice husks mulch, MF: organic fertilizers mulch, and CK: control. Values with various letters indicate significant differences $(P<0.05)$ of mean and \pm denotes the standard errors of the mean $(n=4)$.

Compared to the control (CK), mulch materials had a positive effect on promoting the emergence of bamboo shoots. A significant $(P<0.05)$ increase of 15,18 , and 15 days in the shooting duration was observed for bamboo leaf (MB), rice husk (MR), and organic fertilizer (MF) treatments, respectively compared to CK. In contrast, bamboo treated with MB showed an increase of $47.5 \%$ number of shoots and $21.4 \%$ shoot yield as compared to CK. Similarly, MF increased the number of shoots by $22.7 \%$ and shoot yield by $9.1 \%$ compared to CK. However, MR decreased the number of shoots (29.4 and $15.2 \%$ ) and shoot yield (15.5 and 6.0\%) relative to $\mathrm{MB}$ and $\mathrm{MR}$, respectively.

\subsection{Changes in the Soil Chemical Properties under Various Mulch Treatments}

The introduction of various mulch materials (bamboo, rice, and fertilizer) also altered the dynamics of soil chemical properties; hydrolyzed nitrogen $(\mathrm{HN})$, available phosphorus (AP), and available potassium (AK) (Figure 1).
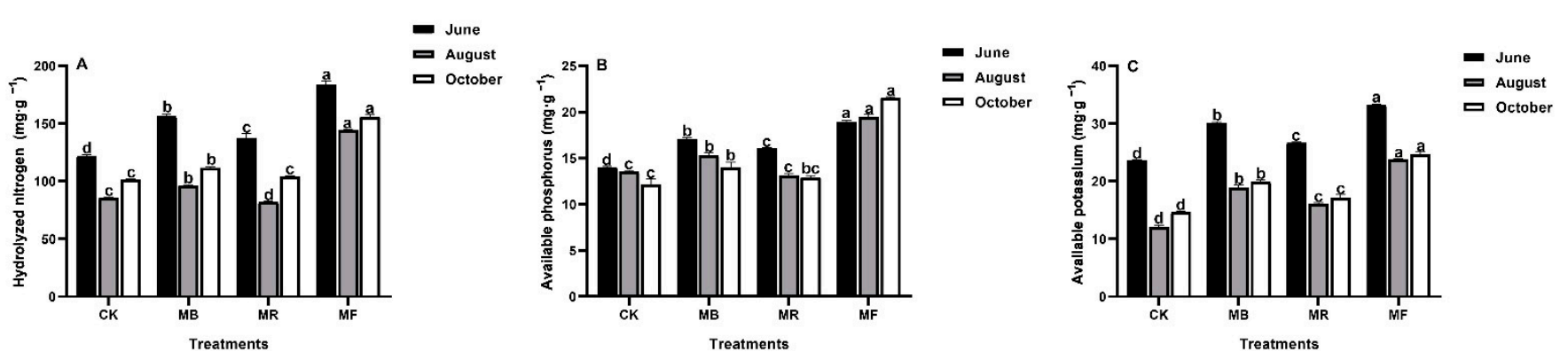

Figure 1. The effect of mulch treatments on soil chemical properties, where MB: bamboo leaves mulch, MR: rice husks mulch, MF: organic fertilizers mulch, and CK: control, respectively. (A) Hydrolyzed nitrogen (HN); (B) Available phosphorus (AP); (C) Available potassium (AK). Various letters on bars show the significant differences $(P<0.05)$ with vertical bars as standard errors $(n=4)$.

Compared to $\mathrm{CK}$, soil $\mathrm{HN}$ content greatly increased under MF and MB treatments in different phases (Figure 1A). Similarly, for AP and AK, MF treatment followed by MB showed significant $(P<0.05)$ effects over $\mathrm{CK}$ (Figure $1 \mathrm{~B}, \mathrm{C})$. Soil $\mathrm{HN}$ and $\mathrm{AK}$ contents were greater in June and October under all mulch treatments (Figure 1A,C). Comparatively, AP was greater in June under MB and MR treatments. In October, MF treatment showed the maximum increase in soil AP relative to other mulch treatments (MB and MR) (Figure 1B).

\subsection{Leaf Chlorophyll Contents under Various Mulch Materials}

The comparisons of various mulch treatments on leaf chlorophyll contents have been summarized in Figure 2. 

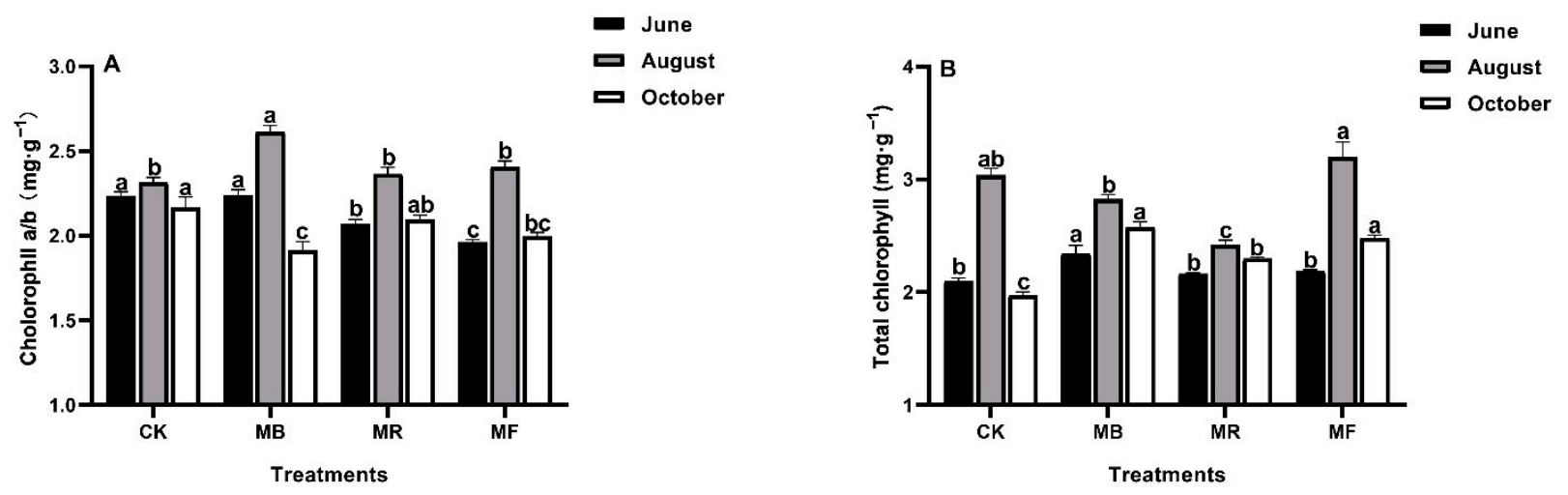

Figure 2. The effect of mulch treatments on leaf chlorophyll contents, where MB: bamboo leaves mulch, MR: rice husks mulch, MF: organic fertilizers mulch, and CK: control. (A) Chlorophyll a/b (Chl a/b); (B) Total chlorophyll (Tc). Various letters on each bar show significant differences $(P<0.05)$ with vertical bars as standard errors $(n=4)$.

In June and October, compared to CK, a slight decrease in chlorophyll a/b (Chl a/b) was observed for MR and MF treatments. However, in August, compared to CK, a significant $(P<0.05)$ increase $(13.0 \%)$ in $\mathrm{Chl} \mathrm{a} / \mathrm{b}$ was observed for $\mathrm{MB}$, following $2.2 \%$ and $4.0 \%$ under MR and MF treatments, respectively (Figure $2 \mathrm{~A}$ ). In June and October, total chlorophyll (Tc) content increased under MB, MR, and MF treatments, respectively over CK. Moreover, in August, Tc content was not influenced under MB and MR treatments compared to CK (Figure 2B).

\subsection{Leaf Soluble Protein Content and Carbohydrate Contents under Various Mulch Treatments}

Various mulch treatments influenced leaf soluble protein and carbohydrates (Figure 3).
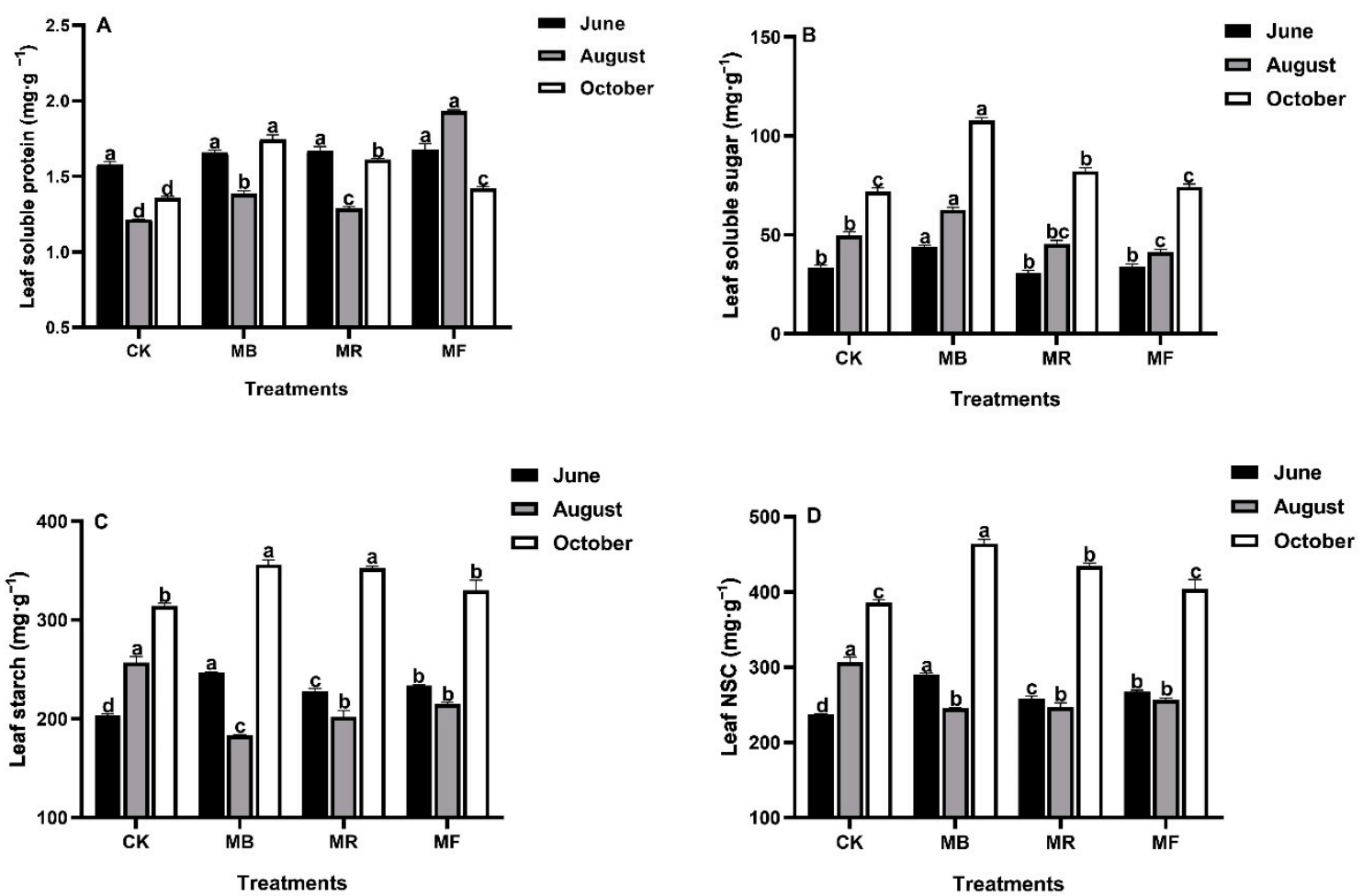

Figure 3. The effect of mulch treatments on leaf soluble protein content and carbohydrate contents, where MB: bamboo leaves mulch, MR: rice husks mulch, MF: organic fertilizers mulch, and CK: control. (A) Leaf soluble protein; (B) Leaf soluble sugar; (C) Leaf starch; (D) Leaf non-structural carbohydrate (NSC). Various letters on each bar show significant differences $(P<0.05)$ with vertical bars as standard errors $(n=4)$. 
In June, mulch treatments did not impact the soluble protein content. However, under MB and MF treatments, the soluble protein content in leaves significantly $(P<0.05)$ increased relative to CK in August and October (Figure 3A). The soluble sugar content also increased linearly under various mulch treatments in June, August, and October. Compared to all other treatments, soluble sugar content of leaves established under MB treatment had the highest values $\left(43.8,62.6\right.$, and $\left.107.8 \mathrm{mg} \mathrm{g}^{-1}\right)$ in June, August, and October, respectively (Figure $3 \mathrm{~B}$ ). Both the leaf starch and non-structural carbohydrate (NSC) contents were significantly $(P<0.05)$ influenced under MB treatment, compared to other treatments in June and October. However, the leaf starch and NSC contents were found to decrease in all mulch treatments in August relative to the other two phases (Figure 3C,D).

\subsection{Carbohydrate Contents in Bamboo Shoots under Various Mulch Treatments}

Compared to $\mathrm{CK}$, mulch treatments had a greater effect on the carbohydrate contents in the bamboo shoots, which contrasted sharply with the leaf carbohydrates (Figure 4).
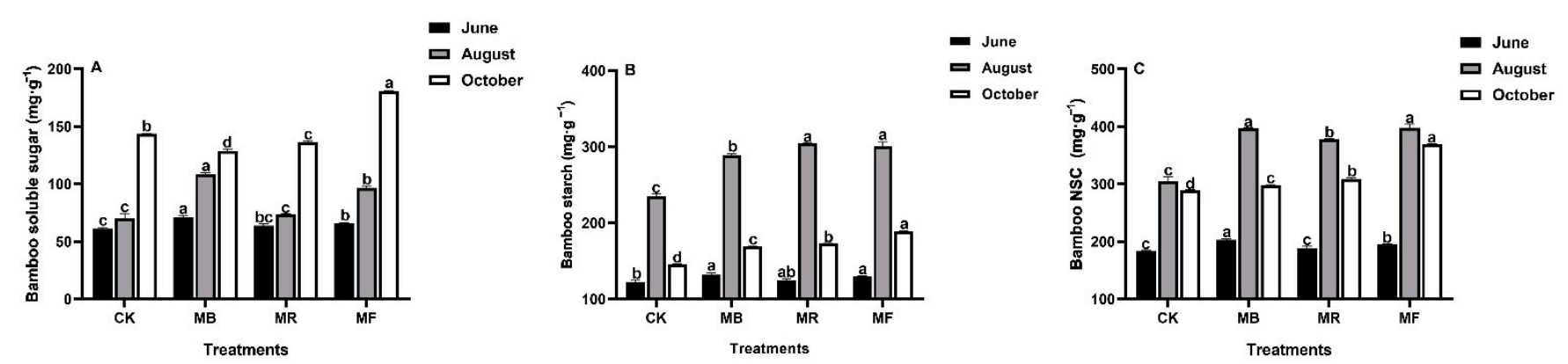

Figure 4. The effect of mulch treatments on carbohydrate contents in bamboo shoots, where MB: bamboo leaves mulch, MR: rice husks mulch, MF: organic fertilizers mulch, and CK: control. (A) Bamboo soluble sugar; (B) Bamboo starch; (C). Bamboo NSC. Various letters on each bar show significant differences $(P<0.05)$ with vertical bars as standard errors $(n=4)$.

MB treatment significantly $(P<0.05)$ affected soluble sugar content of shoots in June and August compared to CK. However, compared to all other mulch treatments, only MF treatment significantly $(P<0.05)$ influenced the soluble sugar content in October (Figure $4 \mathrm{~A})$. In all phases, the starch and NSC contents in bamboo shoots were increased under all mulch treatments relative to CK. Overall, both starch and NSC contents in bamboo shoots were greater in August under all mulch treatments (Figure 4B,C).

\subsection{Principal Component Analysis (PCA) among Bamboo Shoot Indexes, Leaf Physiological Characteristics, and Soil Chemical Properties}

The visual representation of PCA revealed that the cumulative variance contribution rate of the first two principal components reached 91.3\%, which could explain all the variations of the data (Figure 5).

Among them, the first principal component can explain $59.8 \%$ of the total variation. Except for $\mathrm{Chl} \mathrm{a} / \mathrm{b}$, other bamboo shoot indexes, leaf physiological characteristics, and soil chemical properties had positive correlations with PC1, where MB and CK differed greatly. MB showed highly positive correlations with Tc, Lsp, Bs, BNSC, AK, Bss, HN, and AP. MF and MB were positively and negatively correlated to $\mathrm{PC} 2$, respectively, and they had large differences in Lss, LNSC, Ls, By, and Bq, respectively, which had highly positive correlations with PC2. CK was negatively correlated with all indexes. 


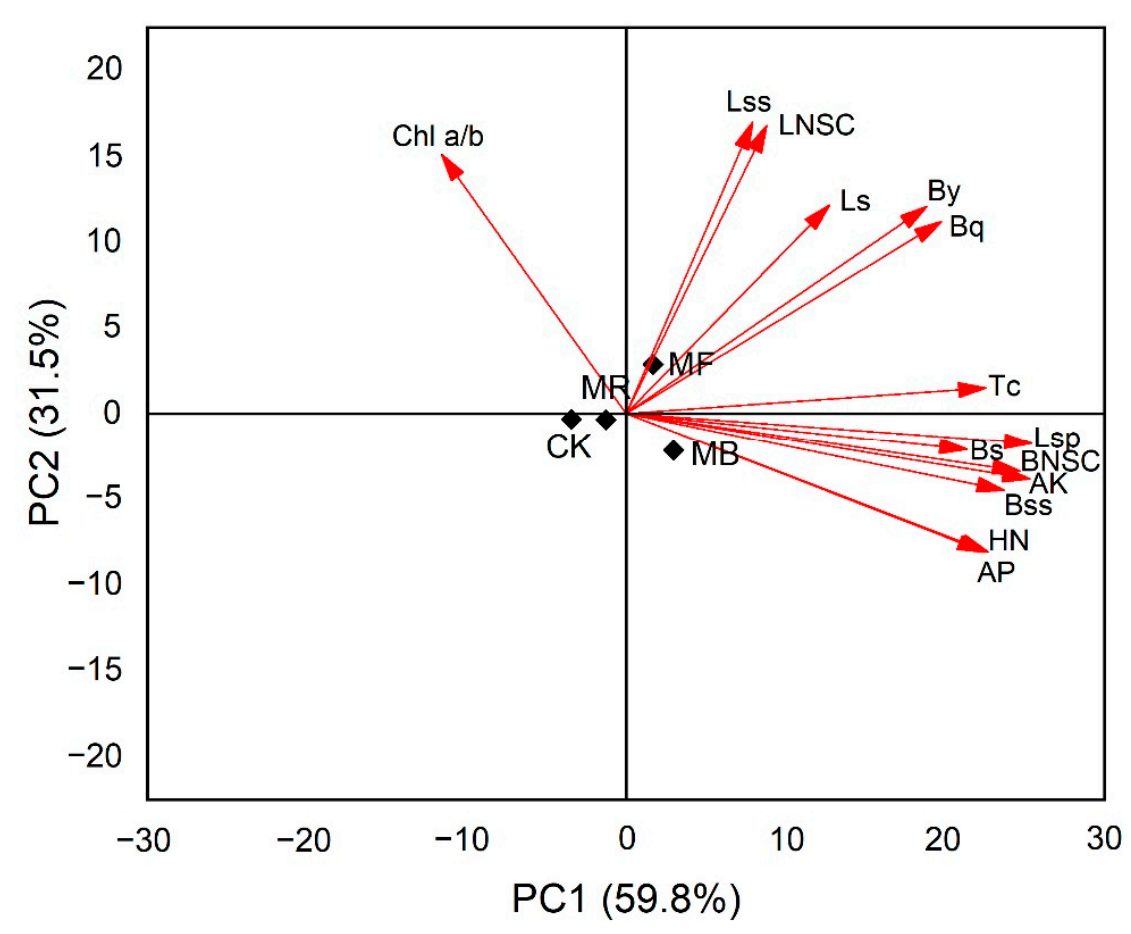

Figure 5. PCA of bamboo shoot indexes, leaf physiological characteristics, and soil chemical indexes, where Bq: the number of bamboo shoots; By: bamboo yield; Bss: bamboo soluble sugar; Bs: bamboo starch; BNSC: bamboo NSC; Chl a/b: chlorophyll a/b; Tc: total chlorophyll; Lsp: leaf soluble protein; Lss: leaf soluble sugar; Ls: leaf starch; LNSC: leaf NSC; HN: hydrolyzed nitrogen; AP: available phosphorus; AK: available potassium. MB: bamboo leaves mulch, MR: rice husks mulch, MF: organic fertilizers mulch, and CK: control.

\section{Discussion}

According to PCA, both MB and MF treatments seem to be more advantageous than MR in terms of improving soil nutrient availability, biochemical characteristics of the leaves and shoots, and bamboo productivity. These findings are associated with severe changes owing to mulching, for instance, mulching has been shown to reduce soil surface temperatures by releasing water vapor via evapotranspiration, conserving soil moisture, retaining soil fertility, and facilitating plant development to enhance their productivity and quality $[26,27]$. As a result, our research provided a new perspective for studying different mulch materials to increase the yield and quality of bamboo shoots, improve soil fertility and leaf physiological status, and optimize bamboo cultivation techniques.

Mulching with bamboo leaves (MB) and organic fertilizer (MF) had substantial effects on optimizing bamboo shooting duration and increasing bamboo yield (Table 1). In comparison to the MB and MF treatments, MR had a minimal impact on improving shoot yield, which exhibited a substantial reduction. The current research findings are consistent with the conclusion of the previous research, using bamboo leaf mulch in P. praecox Prevernalis and P. edulis (Carriere) J. Houzeau [28-30]. The increase in the number of bamboo shoots and yield under MB and MF treatments exhibited strong correlations with the accumulation of more chlorophylls and leaf NSC contents (Figure 5). This may regulate the photosynthesis mechanism and promote the carbohydrate accumulation in D. latiflorus Munro to fulfill the needs of a larger number of bamboo shoots [31,32].

The plants with higher chlorophyll contents have a greater potential for carbon assimilation [33,34]. In our study, Tc content under all mulch treatments was significantly higher than CK in June and October but lower under MB and MR treatments than CK in August (Figure 2B), possibly because the decrease in temperature difference between day and night leads to enhance leaf respiration [35]. Furthermore, soluble sugar is a component of plant photosynthesis apparatus that can be used and transferred directly [36], whereas 
starch is a relatively long-term storage form of plant non-structural carbohydrates for soluble sugars [37]. We found that mulch treatments had significant impacts on both the soluble sugar and starch contents in leaves and promoted the leaf growth at the shoot developmental stage compared to CK, suggesting that D. latiflorus Munro had enhanced NSC transport ability under mulch treatments [38].

The high leaf soluble sugar content under MB treatment can ensure the increase of substances transported to the bamboo berry organs and increase the growth rate of shoots, which has been confirmed by the research of soybeans $[39,40]$. In addition, previous studies have shown that leaf starch (source) can decompose soluble sugars and transfer them to the organ shoots (sink) to promote shoot emergence [41]. Compared to CK, the leaf starch content under the mulch treatments declined sharply in the shooting metaphase with an increase of soluble sugar (Figure 3B,C), indicating that leaf starch decomposed soluble sugars and was imported into the organ shoots to produce a large number of bamboo shoots, which is in accordance with the change of the "source-sink" identity [42,43]. Similarly, previous studies have shown that the accumulation and conversion of abundant NSC to the rice spike is the essential mechanism to maximize the yield of rice grain $[44,45]$. We concluded that mulch materials significantly affected leaf growth responses of $D$. latiflorus Munro to improve the characteristics of bamboo shoots. The improved plant carbon supply and nutrient substances observed in our study could be related to bamboo leaves and organic fertilizer, which can effectively increase carbon assimilation substances in leaves and transfer them to the shoots to ensure shoot germination $[39,40]$.

The significant impact of mulching on plant production is mostly determined by the soil nutrient concentration [17]. With the gradual release of nutrients, such as N, P, and K in the soil, and organic mulch materials, soil nutrients are absorbed and transformed by plants increasingly, and therefore the effect of mulch technology to increase productivity can be apparent [6,46]. In our research, the higher contents of $\mathrm{HN}, \mathrm{AP}$, and AK were increased under mulches (Figure 1), which is consistent with earlier research $[9,13,14]$, demonstrating that mulches can improve the availability of soil essential nutrients stimulating the emergence of shoots and increasing yield. Soil properties may show varying effects to the different mulch treatments [6]. We found the contents of $\mathrm{HN}, \mathrm{AP}$, and AK were generally the highest under MF and MB treatments during the entire shooting period. Additionally, organic fertilizer and bamboo leaves have fast decomposition ability with a high nutrient return to soil $[47,48]$ and can be extremely beneficial to the growth of D. latiflorus Munro.

In the current study, the differences in chlorophyll and bamboo carbohydrates were observed to have a positive correlation with improved soil available nutrients as a result of mulching (Figure 5), which played an important role in triggering photosynthesis activity and increasing the translocation of leaf carbohydrate to shoots $[49,50]$. As stated by [47], MF and MB treatments had better nutrient return to soil, and nutrients availability help to facilitate the greater carbohydrate contents and the growth of mature bamboo shoots (Figure 4). Increased AK content potentially enhances the biosynthesis of soluble protein [51]. As a result, we observed that soil available nutrients with high AK content had a substantial impact on soluble protein (Figure 5), which affected delaying plant senescence, increasing biosynthesis, and reducing the possibility of reduced bamboo yields in the lateral stages $[41,50]$. Previous studies have shown that the retention rate of litter decomposition about rice husk is significantly higher than other mulch materials [52]. As a consequence, the changes in soil available nutrients under rice husk mulch can help to determine the possible reasons that result in less increase of leaf Tc, soluble protein, and carbohydrate contents in bamboo shoots (Figures 2B, 3A, and 4C). We can infer that soil available nutrients ( $\mathrm{HN}, \mathrm{AP}$, and $\mathrm{AK}$ ) varying under various mulches could contribute to the distinct variations in leaf growth (Tc and soluble protein) and NSC accumulations in bamboo shoots, which can help to monitor the growth status of bamboo shoots during the growing phase [53]. 


\section{Materials and Methods}

\subsection{Description of the Study Site}

The present study was carried out in Hongxin Village in Nanjing County, Fujian Province, China. Geographically, it is situated $24^{\circ} 38^{\prime} 52^{\prime \prime} \mathrm{N}$ at latitude, $117^{\circ} 26^{\prime} 53^{\prime \prime} \mathrm{E}$ at longitude. Climatically, the study area falls in the subtropical oceanic monsoon regions of south China. The mean annual temperature is $20.4-22.3{ }^{\circ} \mathrm{C}$ with minimum and maximum temperatures of -2.9 and $40.3{ }^{\circ} \mathrm{C}$, respectively. The mean annual frost-free period is 312 days with the mean annual precipitation of $1798 \mathrm{~mm}$. The soil of the study site is terracotta with a thick humus layer $(60-80 \mathrm{~cm})$ with organic matter $(2.07 \%)$. The basic soil physicochemical properties of the study site are as follows: $\mathrm{pH}=4.6$, total $\mathrm{N}(\mathrm{TN}) 0.7 \mathrm{~g} \cdot \mathrm{kg}^{-1}$, total P (TP) $0.3 \mathrm{~g} \cdot \mathrm{kg}^{-1}$, total K (TK) $14.5 \mathrm{~g} \cdot \mathrm{kg}^{-1}, \mathrm{HN} 175.6 \mathrm{mg} \cdot \mathrm{kg}^{-1}, \mathrm{AP} 8.3 \mathrm{mg} \cdot \mathrm{kg}^{-1}$, and AK $14.6 \mathrm{mg} \cdot \mathrm{kg}^{-1}$. The understory consists of scattered fern, herb, and shrub species, including Dicranopteris pedata (Houttuyn) Nakaike, Miscanthus floridulus (Lab.) Warb. ex Schum et Laut., Rhodomyrtus tomentosa (Ait.) Hassk. The monthly mean temperature and precipitation data during the entire study time (January to October) have been presented in Figure 6. The study site plans to replant Musa nana Lour. into D. latiflorus Munro forests over 10 years.

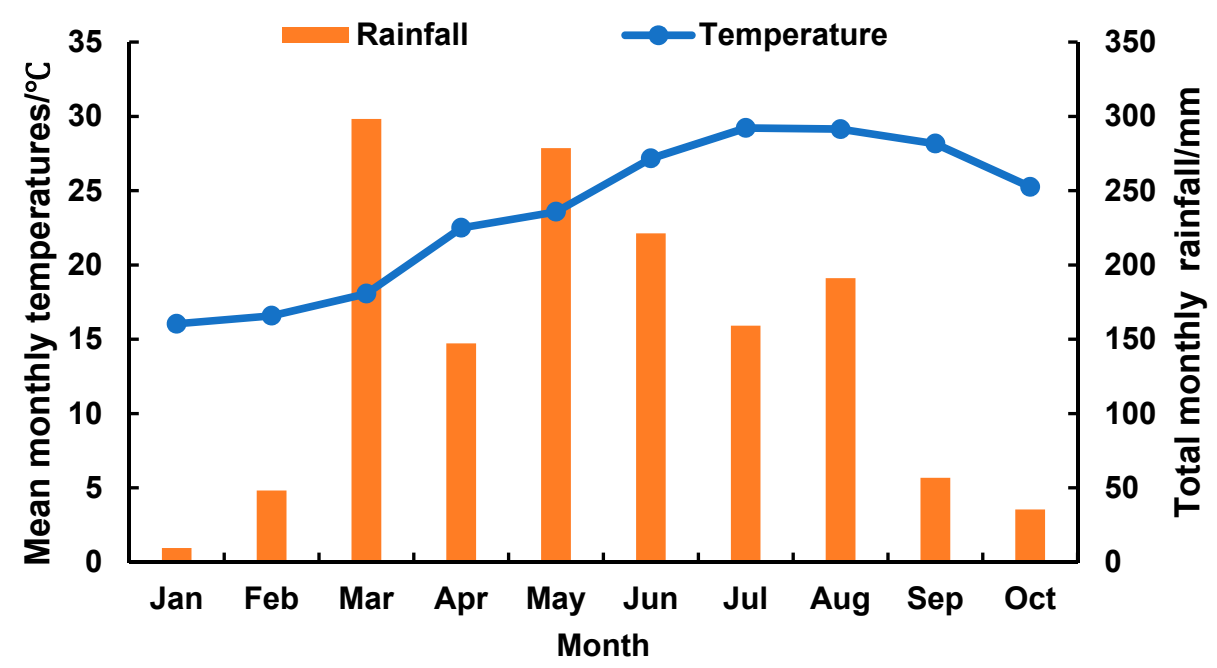

Figure 6. The monthly mean temperature and rainfall from 1 January to 31 October 2019.

\subsection{Description of Plant Material and Sampling Time}

The mulching trial was conducted on 20 December 2018. Land leveling and soiling to cover the entire bamboo stump were carried out before mulching. The density of bamboo was 6-9 individuals per cluster. Three mulch materials were used: bamboo leaves, rice husks, and organic fertilizers, marked as $\mathrm{MB}, \mathrm{MR}$, and $\mathrm{MF}$, and the non-covering treatment as CK. The cow dung was used as organic fertilizer. Based on the thickness of the bamboo stump being $30 \mathrm{~cm}$, the organic fertilizer covered $5 \mathrm{~kg} \cdot \mathrm{m}^{-2}$, the rice husk covered $4.4 \mathrm{~kg} \cdot \mathrm{m}^{-2}$, and the bamboo leaves covered $3.1 \mathrm{~kg} \mathrm{~m}^{-2}$. The chemical characteristics of three mulch materials have been presented in Table 2 .

Table 2. The chemical characteristics of three mulch materials.

\begin{tabular}{cccc}
\hline Mulch Materials & TN $\left(\mathbf{g} \cdot \mathbf{k g}^{-\mathbf{1}}\right)$ & TP $\left(\mathbf{g} \cdot \mathbf{k g}^{-\mathbf{1}}\right)$ & TK $\left.\mathbf{~ g} \cdot \mathbf{k g}^{-\mathbf{1}}\right)$ \\
\hline Bamboo leaves & $29.0 \pm 0.8^{\mathrm{a}}$ & $1.0 \pm 0.1^{\mathrm{b}}$ & $15.6 \pm 0.4^{\mathrm{b}}$ \\
Rice husks & $7.5 \pm 0.2^{\mathrm{b}}$ & $1.1 \pm 0.1^{\mathrm{b}}$ & $13.5 \pm 0.3^{\mathrm{c}}$ \\
Organic fertilizers & $28.9 \pm 0.7^{\mathrm{a}}$ & $4.7 \pm 0.2^{\mathrm{a}}$ & $25.5 \pm 0.7^{\mathrm{a}}$ \\
\hline
\end{tabular}

Values with various letters show the significant differences $(P<0.05)$ with \pm as the standard error of the mean $(n=3)$. 
We selected three plots of $25 \times 25 \mathrm{~m}$ for this experiment. Within each plot, four treatments were arranged in a complete randomized block design representing one replicate. Furthermore, to represent the more sampling area, we also selected four bamboo clusters in the upper, middle, and lower slopes for each treatment in one plot $(25 \times 25 \mathrm{~m})$. The average of four bamboo clusters for each treatment in one plot was considered as one replicate.

Inorganic fertilizers (N:P:K-15:15:15) were applied to all treatments in March (2 kg), June $(2 \mathrm{~kg})$, and August $(1 \mathrm{~kg})$. The fertilization method was circular furrow (the distance to bamboo strips $=20 \mathrm{~cm}$ ). During the experiment, cultural operations such as weeding, insecticide, hooking, and irrigation were managed following normal practices.

On 18 June 2019 (shoots initial-phase), soil samples were collected to determine soil chemical properties (HN, AP, and $\mathrm{AK}$ ) and leaf tissues were sampled to estimate the photosynthetic pigments ( $\mathrm{Chl} \mathrm{a} / \mathrm{b}$ and $\mathrm{Tc}$ ) and biochemical attributes (soluble protein, soluble sugar, and starch). The yield of fresh shoots was determined and bamboo carbohydrates (soluble sugar and starch) were also estimated. Similarly, these attributes were repeatedly measured at the second (16 August, shooting metaphase), and third phase (10 October, shooting anaphase).

\subsection{Investigation of the Bamboo Shoots}

The shooting time of each replicate was recorded from start to end of the experiment. The emergence of each replicate per treatment was calculated by the difference in the first shoot time versus $\mathrm{CK}$. The number of shoots of each replicate (all treatments) were recorded with the interval of three days. The bamboo shoots were trimmed and peeled off the shell after they reached a height of approximately $1.5 \mathrm{~m}$. To determine bamboo shoot yield, the edible portion of bamboo shoots was taken for weighing.

\subsection{Analysis of Soil Chemical Properties}

The soil samples were collected around bamboo stumps at four randomly selected points ( $20 \mathrm{~cm}$ in diameter, $20 \mathrm{~cm}$ depth) in each treatment. The soil was air-dried and sieved through a 2-mm sieve which was used for the estimation of HN, AP, and AK. HN content was measured by sodium hydroxide alkaline solution diffusion method [54], AP content was determined by molybdenum antimony colorimetric method [55], and AK content was estimated by ammonium acetate extraction-flame spectrophotometry [54]. The soil analysis was replicated four times per treatment.

\subsection{Determination of Leaf Biochemical Attributes}

During each phase, upper-middle and healthy leaves samples were collected from each replicate per treatment. Thereafter, samples were preserved with ice bags and were bought to the laboratory at Bamboo Institute of Fujian Agriculture and Forestry University. The samples were washed with distilled water and dried on filter paper.

Leaf chlorophyll contents were directly extracted from $25 \mathrm{~mL}$ mixed solution of acetone, absolute ethanol, and distilled water (4.5:4.5:1) as described by Gao [56] for 48-72 $\mathrm{h}$ in darkness until the leaves' color changed to white completely. The absorbance of the extracted solution was measured by a UV-visible spectrophotometer (TU-1901, Beijing Puxi General Instrument Co., Ltd., Beijing, China) at the wavelengths of 645 and $663 \mathrm{~nm}$. The contents of $\mathrm{Chl}$ a, $\mathrm{Chl} \mathrm{b}$, and Tc were calculated by using the equations of Lichtenthaler [57].

The soluble protein was determined by the chemical kit (Suzhou Keming Biotechnology Co., Ltd., Suzhou, China) of Coomassie brilliant blue method, and the absorbance of the extract was measured at $620 \mathrm{~nm}$ [58]. To measure soluble sugar and starch contents, a portion of fresh leaves were tagged and oven-dried at $105^{\circ} \mathrm{C}$ for $15 \mathrm{~min}$, later at $85^{\circ} \mathrm{C}$ for drying. The dried samples were sieved to $2 \mathrm{~mm}$ and measured by the anthrone sulfuric acid method [59], and their absorbances were tested at the wavelength of $540 \mathrm{~nm}$ and $620 \mathrm{~nm}$ using a spectrophotometer. The NSC contents were calculated by the sum of the soluble sugar and starch contents. All leaf chemical analyses were replicated four times in each treatment. 


\subsection{Determination of Carbohydrate Content in Bamboo Shoots}

During each phase, bamboo shoots with a height of 20-30 cm were collected from each replicate per treatment, preserved in ice bags, and brought back to the Bamboo Research Institute of Fujian Agriculture and Forestry University for estimation of carbohydrate contents. First, the bamboo shoots were peeled off, washed with distilled water, and dried on filter paper. Thereafter, these were chopped and placed in a kraft paper bag and oven-dried at $105^{\circ} \mathrm{C}$ for $15 \mathrm{~min}$, and later at $85^{\circ} \mathrm{C}$ for drying. The dried samples were grinded and sieved through a 2-mm sieve. The determination method and calculation formula of starch and soluble sugar of bamboo shoots were consistent with that of leaves. The analysis was replicated four times per treatment.

\subsection{Data Analysis}

The data were statistically analyzed with SPSS-22.0 by applying one-way ANOVA per time following multiple comparison tests (LSD and Dunnett's T3) to determine the significant differences $(\alpha 0.05)$. The average statistical data in three phases was adopted for PCA to analyze relationships among shoot characteristics, leaf biochemical attributes, and soil chemical properties under different treatments. Origin-lab 9.5, Prism-8.0.1, and Microsoft Excel-2016 were used for visualization and tables, respectively.

\section{Conclusions}

The findings of the present research suggest that the mulches can improve the bamboo shoot characteristics, but their effect may differ. PCA analysis revealed that mulch materials, such as $\mathrm{MB}$ and $\mathrm{MF}$, both had a positive impact on improving the characteristics of bamboo shoots. The mulch treatments also influenced the availability of soil nutrients and biochemical characteristics of the leaves and shoots. There was a strong positive correlation between the number of shoots, the yield of shoots, and the carbohydrate contents of leaves, indicating that a large amount of accumulation of leaf photosynthetic products from leaves were transferred to bamboo shoots to promote emergence and growth. Considering the effect of various mulch materials, we conclude that both MB and MF appear to be a better choice than MR to improve bamboo productivity by increasing soil available nutrients, and biochemical traits of the leaves and shoots. Furthermore, the addition of organic fertilizer to the bamboo stands can meet the nutrient requirements of a large number of shoots during the shooting period and improve bamboo shoot quality. Therefore, we recommend the utilization of organic fertilizers and bamboo leaves as mulch materials as effective for soil conservation to attain high-quality bamboo production.

Author Contributions: Conceptualization, L.F., T.Z., J.R. and Y.Z.; methodology, L.F.; software, L.F.; validation, Y.Z. and M.W.K.T.; formal analysis, L.F. and M.W.K.T.; investigation, L.F., T.Z., Y.H. and W.H.; resources, Y.Z.; data curation, L.F.; writing—original draft preparation, L.F.; writing—review and editing, L.F. and M.W.K.T.; visualization, L.F.; supervision, J.R. and Y.Z.; project administration, Y.Z., J.R. and T.H.; funding acquisition, Y.Z., J.R. and T.H. All authors have read and agreed to the published version of the manuscript.

Funding: This work was supported by the National Key R \& D Program of China" (2018YFD0600100) and Program for Scientific and Technological Innovation Teams for Universities of Fujian Province (No. 2018[49]).

Institutional Review Board Statement: Not applicable.

Informed Consent Statement: Not applicable.

Data Availability Statement: The data presented in this study are available in the article.

Conflicts of Interest: The authors declare no conflict of interest. 


\section{References}

1. Chalker-Scott, L. Impact of mulches on landscape plants and the environment-A review. J. Environ. Hortic. 2007, 25, 239-249. [CrossRef]

2. Greenly, K.M.; Rakow, D.A. The effect of wood mulch type and depth on weed and tree growth and certain soil parameters. J. Arboric. 1995, 21, 225.

3. Gleason, M.L.; Iles, J.K. Mulch matters: The proper use of organic mulch offers numerous benefits for your woody landscape plants. Am. Nurserym. 1998, 187, 24-31.

4. Rathinasabapathi, B.; Ferguson, J.; Gal, M. Evaluation of allelopathic potential of wood chips for weed suppression in horticultural production systems. HortScience 2005, 40, 711-713. [CrossRef]

5. Hanada, T. The Effect of Mulching and Row Covers on Vegetable Production; ASPAC, Food \& Fertilizer Technology: Taipei, Taiwan, 1991.

6. Ni, X.; Song, W.; Zhang, H.; Yang, X.; Wang, L. Effects of mulching on soil properties and growth of tea olive (Osmanthus fragrans). PLoS ONE 2016, 11, e0158228. [CrossRef] [PubMed]

7. Kumar, V. Effect of different organic mulching materials on soil properties of Na ' 7' Aonla (Emblica Officinalis Gaertn) under rainfed condition of shiwalik foothills of Himalayas India. Bioscan 2014, 9, 561-564.

8. Guo, X.; Chen, H.; Liu, Y.; Chen, W.; Ying, Y.; Han, J.; Gui, R.; Zhang, H. The acid invertase gene family is involved in internode elongation in Phyllostachys heterocycla cv. pubescens. Tree Physiol. 2020, 40, 1217-1231. [CrossRef] [PubMed]

9. Liu, S.; Zhang, L.; Li, Z.; Jia, J.; Fan, F.; Shi, Y. Effects of plastic mulch on soil moisture and temperature and limiting factors to yield increase for dryland spring maize in the North China. J. Appl. Ecol. 2014, 25, 3197-3206. [CrossRef]

10. Zhu, Z.; Wang, B.; Zhu, W.; Wang, K.; Li, Q.; Yang, J. Mulching technology for shooting of spring-shoot in shoot forest of Phyllostachy edulis during the winter. World Bamboo Ratt. 2014, 12, 19-21. [CrossRef]

11. Wu, J. The effects of different mulches on the yield of bamboo shoots of D. beecheyana var. pubescens. J. Fujian For. Sci. Technol. 2016, 43, 134-136,140. (In Chinese) [CrossRef]

12. Wang, H.; Zeng, Q.; Yang, J.; Cheng, P.; Yu, L. Effects of different forestry measures on shooting period and yield of winter shoots in Phyllostachy edulis. J. Bamboo Res. 2017, 36, 30-35. (In Chinese) [CrossRef]

13. Zhou, J.; Lü, D.; Qin, S. Effects of different organic matter mulching on water content, temperature, and available nutrients of apple orchard soil in a cold region. J. Appl. Ecol. 2014, 25, 2551-2556.

14. Akhtar, K.; Wang, W.; Ren, G.; Khan, A.; Feng, Y.; Yang, G.; Wang, H. Integrated use of straw mulch with nitrogen fertilizer improves soil functionality and soybean production. Environ. Int. 2019, 132, 105092. [CrossRef] [PubMed]

15. Chen, S.; Chen, C.; Wang, W.; Yang, Q. Study on shooting hastening techniques of Dendrocalamopsis oldhami. J. Southwest For. Coll. 2004, 24, 17-20. (In Chinese)

16. Chen, R.; Wang, L.; Zhai, H.; Xue, X.; Wang, J. Effects of organic material coverage on soil microenvironment, tree growth and photosynthetic rate. Tianjin Agric. Sci. 2019, 25, 18-21. (In Chinese) [CrossRef]

17. Dong, W.; Si, P.; Liu, E.; Yan, C.; Zhang, Z.; Zhang, Y. Influence of film mulching on soil microbial community in a rainfed region of northeastern China. Sci. Rep. 2017, 7, 8468. [CrossRef]

18. Kahlon, M.S.; Lal, R.; Ann-Varughese, M. Twenty two years of tillage and mulching impacts on soil physical characteristics and carbon sequestration in central ohio. Soil Tillage Res. 2013, 126, 151-158. [CrossRef]

19. Li, T.; Xie, Y.; Gao, Z.; Hong, J.; Li, L.; Meng, H.; Ma, H.; Jia, J. Year-round film mulching system with monitored fertilization management improve grain yield and water and nitrogen use efficiencies of winter wheat in the dryland of the Loess Plateau, China. Environ. Sci. Pollut. Res. Int. 2019, 26, 9524-9535. [CrossRef]

20. Wang, X.; Xing, Y. Effects of mulching and nitrogen on soil nitrate-N distribution, leaching and nitrogen use efficiency of maize (zea mays L.). PLoS ONE 2016, 11, e0161612. [CrossRef] [PubMed]

21. Luo, C.; Zhang, X.; Duan, H.; Mburu, D.M.; Ren, H.; Kavagi, L.; Dai, R.; Xiong, Y. Dual plastic film and straw mulching boosts wheat productivity and soil quality under the El Nino in semiarid Kenya. Sci. Total Environ. 2020, 738, 139808. [CrossRef]

22. Duan, J.; Shao, Y.; He, L.; Li, X.; Hou, G.; Li, S.; Feng, W.; Zhu, Y.; Wang, Y.; Xie, Y. Optimizing nitrogen management to achieve high yield, high nitrogen efficiency and low nitrogen emission in winter wheat. Sci. Total Environ. 2019, 697, 134088. [CrossRef] [PubMed]

23. Irshad, M.; Ullah, F.; Fahad, S.; Mehmood, S.; Danish, S. Evaluation of Jatropha curcas L. leaves mulching on wheat growth and biochemical attributes under water stress. BMC Plant Biol. 2021, 21, 303. [CrossRef] [PubMed]

24. He, X.; Zheng, Z.; Li, T.; He, S.; Lin, C. Transport of colloidal phosphorus in runoff and sediment on sloping farmland in the purple soil area of south-western China. Environ. Sci. Pollut. Res. 2019, 26, 24088-24098. [CrossRef]

25. Lin, L.; Chang, F.; Ko, C.; Wang, C. Bamboo-derived fuel from Dendrocalamus latiflorus, Phyllostachys makinoi, and Phyllostachys pubescens waste. BioResources 2016, 11, 8425-8434. [CrossRef]

26. Slathia, P.S.; Paul, N. Traditional practices for sustainable livelihood in Kandi belt of Jammu. Indian J. Tradit. Knowl. 2012, 11, 548-552.

27. Shirgure, P.S.; Sonkar, R.K.; Singh, S.; Panigrahi, P. Effect of different mulches on soil moisture conservation, weed reduction, growth and yield of drip irrigated Nagpur mandarin (Citrus reticulata). Indian J. Agric. Sci. 2003, 73, 148-152. [CrossRef]

28. Wang, K.; Weng, F.; Wu, R. Research on bamboo shoots of winter in bamboo and bamboo-shoot forest. J. Bamboo Res. 2001, 21, 27-31. (In Chinese) 
29. Jiang, P.; Xu, Q.; Qian, X.; Zhang, R.; Yang, F. Dynamic changes of chemical properties of warmer soil covered with different organic materials in Phyllostachy praecox forests. J. Zhejiang For. Coll. 1999, 16, 123-130. (In Chinese)

30. Su, Y.; Liu, H.; Li, X.; Fan, C.; Liu, S.; Zhang, X.; Liuman, C. Responses of soil stoichiometry characteristic and fertilizer contribution rate to intensive management in a Phyllostachys praecox forest. J. Sichuan Agric. Univ. 2018, 36, 751-757,784. (In Chinese) [CrossRef]

31. Jin, H.; Li, M.; Duan, S.; Fu, M.; Dong, X.; Liu, B.; Feng, D.; Wang, J.; Wang, H. Optimization of light-harvesting pigment improves photosynthetic efficiency. Plant Physiol. 2016, 172, 1720-1731. [CrossRef] [PubMed]

32. Wu, G.; Ma, L.; Sayre, R.T.; Lee, C.-H. Identification of the optimal light harvesting antenna size for high-light stress mitigation in plants. Front. Plant Sci. 2020, 11, 505. [CrossRef] [PubMed]

33. Evans, J.R.; Poorter, H. Photosynthetic acclimation of plants to growth irradiance: The relative importance of specific leaf area and nitrogen partitioning in maximizing carbon gain. Plant. Cell Environ. 2001, 24, 755-767. [CrossRef]

34. Moreau, D.; Allard, V.; Gaju, O.; Le Gouis, J.; Foulkes, M.J.; Martre, P. Acclimation of leaf nitrogen to vertical light gradient at anthesis in wheat is a whole-plant process that scales with the size of the canopy. Plant Physiol. 2012, 160, 1479-1490. [CrossRef] [PubMed]

35. Gratani, L.; Crescente, M.F.; Varone, L.; Fabrini, G.; Digiulio, E. Growth pattern and photosynthetic activity of different bamboo species growing in the Botanical Garden of Rome. Flora-Morphol. Distrib. Funct. Ecol. Plants 2008, 203, 77-84. [CrossRef]

36. Tarin, M.W.K.; Fan, L.; Lai, J.; Li, J.; Deng, Z.; Chen, L.; He, T.; Rong, J.; Zheng, Y. Rice straw biochar impact on physiological and biochemical attributes of Fokienia hodginsii in acidic soil. Scand. J. For. Res. 2020, 35, 59-68. [CrossRef]

37. Vojvodic, A.; Komes, D.; Belscakcvitanovic, A.; Busic, A.; Santek, B. Composition of non-structural and structural carbohydrates in plant secondary raw materials. In Proceedings of the Book of Abstracts of the International Congress on Engineering \& Food, Québec City, QC, Canada, 14-18 June 2015.

38. Xu, B.; You, C.; Ding, Y.; Wang, S. Effect of source-sink manipulation on translocation of carbohydrate and nitrogen, phosphors, potassium in vegetative organs of conventional Japonica rice after anthesis. Sci. Agric. Sin. 2016, 49, 643-656. (In Chinese) [CrossRef]

39. Hu, X.; Sun, L.; Luo, S.; Liu, Y. Effect of integrated nutrient management on accumulation and distribution of soluble sugar and yield of soybean. J. Northeast Agric. Univ. 2011, 42, 8-12. (In Chinese) [CrossRef]

40. Xia, D.; Bai, Z.; Liu, B.; Yao, B.; Li, D.; Zhang, Z. Changes of protective enzyme activities in leaves senescence of soybean cultivars bred at different ages in jilin province. Mol. Plant Breed. 2018, 16, 228-233. [CrossRef]

41. Masclaux, C.; Valadier, M.-H.; Brugière, N.; Morot-Gaudry, J.-F.; Hirel, B. Characterization of the sink/source transition in tobacco (Nicotiana tabacum L.) shoots in relation to nitrogen management and leaf senescence. Planta 2000, 211, 510-518. [CrossRef]

42. Egli, D. Source-sink relationships, seed sucrose levels and seed growth rates in soybean. Ann. Bot. 2001, 88, 235-242. [CrossRef]

43. Heuvel, J.E. Vanden Source-sink relationships in cranberry: Effects on carbohydrate production and partitioning. HortScience 2004, 39, 761A-761. [CrossRef]

44. Nagata, K.; Yoshinaga, S.; Takanashi, J.I.; Terao, T. Effects of dry matter production, translocation of nonstructural carbohydrates and nitrogen application on grain filling in rice cultivar takanari, a cultivar bearing a large number of spikelets. Plant Prod. Sci. 2001, 4, 173-183. [CrossRef]

45. Pan, J.; Wang, B.; Cui, K.; Huang, J.; Nie, L. Effects of nitrogen application on accumulation and translocation of non-structural carbohydrates in internodes and sheaths of rice. Chin. J. Rice Sci. 2016, 273-282. [CrossRef]

46. Renáta, P.; Zalai, M.; Bogdányi, F.T.; Tóth, F. The effect of organic mulching and irrigation on the weed species composition and the soil weed seed bank of tomato. Plants (Basel) 2020, 9, 66. [CrossRef]

47. Zhang, J.; Li, B.; Zhang, J.; Christie, P.; Li, X. Organic fertilizer application and Mg fertilizer promote banana yield and quality in an Udic Ferralsol. PLoS ONE 2020, 15, e0230593. [CrossRef] [PubMed]

48. Wang, X.; Wang, G.; Turner, N.C.; Xing, Y.; Li, M.; Guo, T. Determining optimal mulching, planting density, and nitrogen application to increase maize grain yield and nitrogen translocation efficiency in Northwest China. BMC Plant Biol. 2020, $20,282$. [CrossRef] [PubMed]

49. Houdusse, F.; María, G.; Jose María, G.-M. Nitrogen fertiliser source effects on the growth and mineral nutrition of pepper (Capsicum annuum L.) and wheat (Triticum aestivum L.). J. Sci. Food Agric. 2010, 87, 2099-2105. [CrossRef]

50. Soltabayeva, A.; Srivastava, S.; Kurmanbayeva, A.; Bekturova, A.; Fluhr, R.; Sagi, M. Early senescence in older leaves of low nitrate-grown atxdh1 uncovers a role for purine catabolism in N supply. Plant Physiol. 2018, 178, 1027-1044. [CrossRef] [PubMed]

51. Ibrahim, M.; Jaafar, H.; Karimi, E.; Ghasemzadeh, A. Primary, secondary metabolites, photosynthetic capacity and antioxidant activity of the malaysian herb kacip fatimah (Labisia Pumila Benth) exposed to potassium fertilization under greenhouse conditions. Int. J. Mol. Sci. 2012, 13, 15321-15342. [CrossRef]

52. Truong, T.H.H.; Marschner, P. Plant residues differing in $\mathrm{C} / \mathrm{N}$ ratio in mulch and soil-The effect of the mulch on nutrient availability and microbial biomass is more pronounced with higher leaching amount. Soil Ecol. Lett. 2020, 2, 317-326. [CrossRef]

53. Wu, J.; Xu, Q.; Jiang, P.; Cao, Z. Dynamics and distribution of nutrition elements in bamboos. J. Plant Nutr. 2009, 32, 489-501. [CrossRef]

54. Pansu, M.; Gautheyrou, J. Handbook of Soil Analysis Mineralogical, Organic and Inorganic Methods: Mineralogical, Organic and Inorganic Methods; Springer Science \& Business Media: Berlin/Heidelberg, Germany, 2007; ISBN 3540312110. 
55. Watanabe, F.S.; Olsen, S.R. Test of an ascorbic acid method for determining phosphorus in water and NaHCO3 extracts from soil. Soil Sci. Soc. Am. J. 1965, 29, 677-678. [CrossRef]

56. Gao, J. Experimental Guide of Plant Physiology; Higher Education Press: Beijing, China, 2006.

57. Lichtenthaler, H.K. Chlorophylls and carotenoids: Pigments of photosynthetic biomembranes. Methods Enzymol. 1987, 148, 350-382

58. Tarin, M.W.K.; Fan, L.; Tayyab, M.; Sarfraz, R.; Chen, L.; He, T.; Rong, J.; Chen, L.; Zheng, Y. Effects of bamboo biochar amendment on the growth and physiological characteristics of Fokienia hodginsii. Appl. Ecol. Environ. Res. 2018, 16, 8055-8074. [CrossRef]

59. Laurentin, A.; Edwards, C.A. A microtiter modification of the anthrone-sulfuric acid colorimetric assay for glucose-based carbohydrates. Anal. Biochem. 2003, 315, 143-145. [CrossRef] 